\title{
流れ計算のための航空機外郭と物理空間の計算格子*1 \\ Out Surface of Airplane and Computational Grid for Flow Analysis in Physical Space
}

\author{
中 村 正 義*2 \\ Masayoshi NAKAMURA
}

Key Words: Out Surface of Airplane, Computational Grid in Physical Space,

Figure of Airplane

\begin{abstract}
For the purpose of numerical analysis of threedimensional compressible steady flow around an airplane, it is necessary to find quantitatively local positions of an out surface of the airplane and local directions of the surface in a rectangular computational grid system in physical space. The out surface of airplane is made up of many elements of small triangular planes. The local positions of the out surface in the grid system are determined by local intersections of axes of the grid with these triangular planes. Directions of the triangular planes are substituted for the local directions of the out surfaces. Using these results, views of the out surface of airplane are drawn in sheets of paper.
\end{abstract}

\section{1. まえがき}

航空機の設計において空気力学的な諸性能を見積も る手段に電子計算機を用いた流れの解析計算がある. 計算による航空機の空気力学的な性能の予測は、実験 による場合と比較してより簡便に航空機のおかれた 種々の状態の性能を細部にわたって知ることも可能で ある.そして電子計算機と数值解析法の発達に伴って 計算の対象にできる航空機の形状はより現実のものに 近くなっている ${ }^{1,2)}$.この報告は，航空機を過ぎる流 れの物理空間における数值解析法の開発の一環として 電子計算機に認識させる航空機の外郭のとり方と数値 解析に用いる計算格子に関して記述するものである.

航空機を過ぎる流れを計算するためには流れに接す る航空機の表面形状の計算機による認識が必要であ る.航空機を構成する胴体，主翼等の構成部分の表面 を微小な三角形の面（以下便宜上「三角面」と呼ぶ） の集りとして表現し，これらの構成部分を結合して三

*1 昭和 60 年 2 月 4 日原稿受理

*2 航空宇宙技術研究所
角面で覆われた航空機外郭をつくる，航空機を過ぎる 流れの解析に使用する方程式の変数として速度ポテン シャルを予定している゙” また数值解析に用いる差分 計算用の格子は物理空間内で直交する直線格子を予定 している．この場合，航空機の外郭における境界条件 を定めるために外郭の法線の方向が必要になる. 航空 機外郭の局所的な法線方向は, その場所を形成する三 角面のもつ法線方向である。また計算格子と航空機の 外郭の位置関係は，計算格子を形成する直線と航空機 の外郭を形成する三角面の三次元空間内の位置関係か ら定められる，計算格子内の格子点には，航空機の外 郭の外側にあって流れの計算に必要なものと，航空機 の内部に位置して流れ場と独立した空間内にある格子 点の二種類ある.この区別も格子を形成する直線と航 空機外部を形成する三角面の幾何学的な位置関係を利 用して行う。

航空機の一例として, 胴体、主翼，水平尾翼，垂直 尾翼、エンジン・ナセルおよびフラップを備えた旅客 用の民間航空機を想定して，その外郭をつくる．そし て航空機の外郭を形成する三角面を四枚一組として扱 い描写上の煩雑を避け慣例に従った方法でその外郭を 紙面に描いて航空機外郭の視覚的認識の手段とする.

\section{2. 航空機外郭と計算格子の形成}

航空機の構成部分の各外郭を微小な三角面の集合体 として表現する．その三角面は三次元空間の平面の一 部であり，その平面は直交直線座標系 $(x, y, z) に お ~$ いて次の式で表される゙

$$
l x+m y+n z=p
$$

ただし $|p|$ は座標の原点から平面までの距離を表し， $l, m, n$ はその平面の法線の $x, y, z$ 軸に対する方向 余弦をそれぞれ示す たとえば第 1 図に示すように航 空機の外郭を形成する一つの三角面を三角面 ABC と する.この三角面の一つの垂直線を線分 DEと書いて 
その長さを 1 とした場合，三角面 $\mathrm{ABC}$ の三つの頂点 の座標值を用いて，（1）式からこの三角面 $\mathrm{ABC}$ の垂 直線の方向余弦 $l, m, n$ が算出できる.そして航空機 外郭任意位置の法線方向は，その場所を形成する三角 面の垂直線の方向余弦から定まる．航空機の構成部分 の外郭をそれぞれ独立に三角面で表して各構成部分を 結合させて一つの航空機の外郭とする，この場合，各 構成部分間にかみ合い線が生じる．その線は局部的に は各構成部分の外郭を形成する三角面が互いに交わる ときにつくる線である。この線は交わる三角面を含む 平面の交線の一部として求めることができる．一般に 三次元空間での直線の方程式は次式で表される"，

$$
\frac{x-x_{0}}{l}=\frac{y-y_{0}}{m}=\frac{z-z_{0}}{n}
$$

ただしこの $l, m, n$ はその直線の方向余弦を示し,$x_{0}$, $y_{0}, z_{0}$ はその直線上の任意の点における $x, y, z$ 軸上 のそれぞれの座標值とする．上述の平面の交線は一般 $k$ (2) 式の形で得られ, 三角面の交線を定めること がてきる。この交線は航空機外郭の表現図に必要であ り計算格子との関係では必要性はない。計算格子と航 空機の外郭の関係は，格子を形成する直線と外郭を形 成する三角面との関係で表現される。すなわち直線を 表す（2）式と平面を表す（1）式から格子と航空機 外郭の交点の位置が定まる。

航空機のまわりの流れを物理空間の直交格子による 差分計算て解く場合，航空機の外郭近傍に位置する格 子点および格子と外郭との交点である境界点における 差分近似式の取扱いに配慮が必要になる．その格子点 における差分式は，その格子点から航空機外郭上の境 界点までの距離が必要でありまた境界点の法線方向が 間接的に必要になる。これらの距離や法線方向の算出 はすへてて（1）および（2）式を用いて行われた．第 2図に示すように航空機の外郭を形成する一つの三角

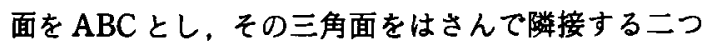
の格子点を $\mathrm{P}, \mathrm{Q}$ とする．この格子点 $\mathrm{P}, \mathrm{Q}$ を結ぶ格子

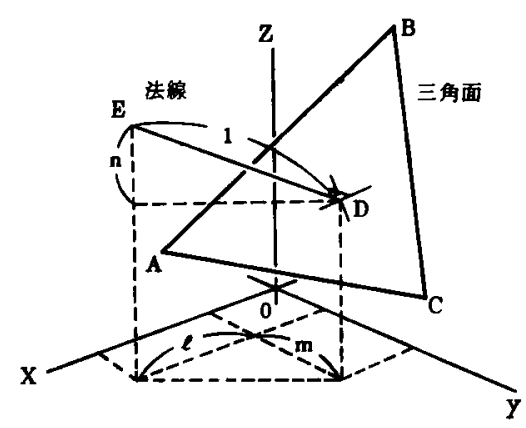

第 1 図三角面とその法線
の軸と三角面 $\mathrm{ABC}$ の交点である境界点 $\mathrm{D}$ は, 格子点 $\mathrm{P}, \mathrm{Q}$ を通る直線の方程式と三角面 $\mathrm{ABC}$ を含む平面の 方程式から算出されその位置が定められる。 そして格 子点と境界点の距離である $\mathrm{PD}$ または $\mathrm{QD}$ の長さが決 まる．また境界点 Dにおける航空機外郭の法線方向 は三角面 $\mathrm{ABC}$ の法線方向 $\mathrm{EE}^{\prime}$ として定まる。この場 合格子点 $\mathrm{P}$ に対する境界点 $\mathrm{D}$ の法線の向きは $\overrightarrow{\mathrm{DE}}$ あり格子点 $\mathrm{Q} に$ 対するそれは $\overrightarrow{\mathrm{DE}}$ となる。この法線 の向きの区別も格子点と三角面のおかれた位直関係か ら定められる。

計算格子は航空機の外郭の外部空間扔よび内部空間 を問わず一様に分布されている．そのために計算格子 点が航空機外郭の外側領域か，すなわち流れを計算す る領域内にあるかそれとも外郭の内部領域にあり流れ の計算に不必要な点か，の区別をする必要がある．た とえば先の第 2 図でいえば、格子点 $\mathrm{P}$ あるいは $Q$ が 航空機の外郭の外部空間に属するか，内部空間に属す るかあるいはその両方かの区別である.この判断は航 空機外郭を形成する三角面と格子点の局部的な位置関 係だけで行うことは不可能であり。航空機外郭と計算 格子全体の総合的な関係で判断しなければならない. その判断の一つの方法として，第 3 図に示すように計 算格子の中に閉じた外郭 Sを持つ物体がおかれた場 合を考える、はじめに明らかに物体の外郭の外部領域 にある一つの格子点を決める．この格子点を同図では $\mathrm{F}$ とする．次に任意の格子点をとり，この格子点から 格子を形成する軸に沿って物体の外郭 S を貫通しな いで格子点 $\mathrm{F}$ に到達できる場合，この格子点は物体 の外郭の外部領域に属するものと判断した．たとえば 同図の格子点 $\mathrm{G}$ は外郭 $\mathrm{S}$ を貫通しないて格子点 $\mathrm{F} に$ 到達できる。しかし格子点 $\mathrm{H}$ はそれは不可能であり， この場合格子点 $\mathrm{G}$ は外部， $\mathrm{H}$ は内部領域にあるとし た。

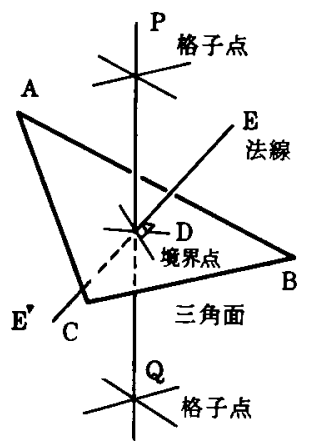

第 2 図格子点と三角面 


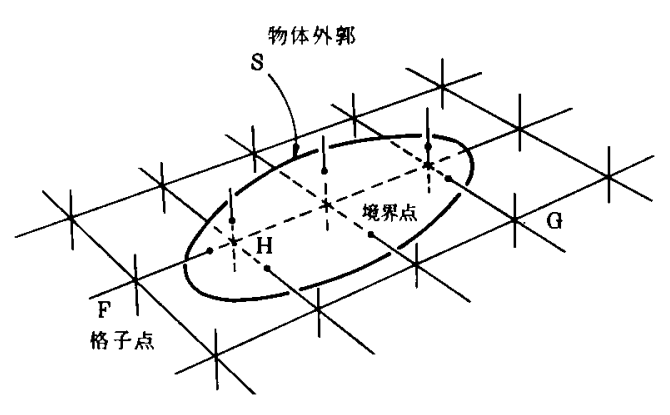

第 3 図 物体外部の格子点識別の説明図

\section{3. 航空機外郭と計算格子の例}

3.1 航空機外郭表現図 航空機外郭を三角面の集 合体で表現したが，外郭座標値の与え方の煩雑さの回 避と慣習的な作図の立場から，外郭を形成する三角面 を原則として四枚一組で扱う，その四つの三角面は第 4 図左に示すように隣り合う三角面が一つの頂点を共 有し，かつ四つの各三角面の一つの頂点が共通点とな るものである．四つの三角面の頂点である同図の五つ の点は同図右に示すように一般に一平面上にはない. ここでは，航空機の構成部分の形状の長軸に浻った断 面形の輪郭の座標値を与え，それらの值からその構成 部分の外郭を形成する四つ一組の三角面の頂点の座標 值を求める. 構成部分の外郭の形状によっては部分的 に一つの三角面を単独で扱うこともある. 三次元空間 内の航空機の外郭を二次元の紙面に作図する場合，外 郭を形成する三角面のすべての辺を描写すると見にく くなる．たとえば第 5 図左にスケッチした立方体の表 面の各面を上述のような四つの三角面て構成させてそ れらの三角面のすへてての辺を描いた同図右の場合、一 つの面の四つの三角面が同一平面内にあるにもかかわ らず不必要な線が加わり視覚感を阻害する．そこで四 つ一組の三角面の共通てない四つの辺，すなわち外周 を描写する方法を慣例に従ってとった，例外として先 の第 4 図右に示すように，四つ一組の三角面を見る角 度によっては三角面の共通する辺が稜線として現われ る場合、その辺は描くことにした。しかしながらこれ
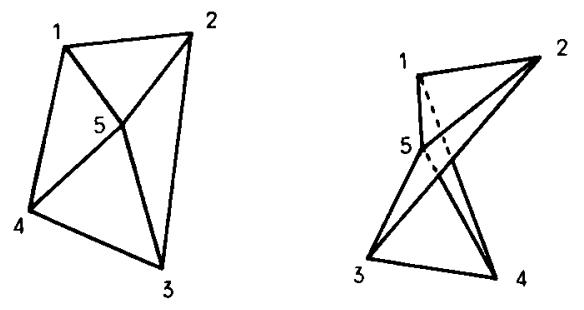

第 4 図四つ一組の三角面
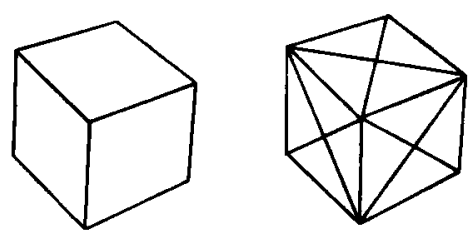

第 5 図 立方体の表現図

らは作図上の技術的手段に限ったものであり，航空機 外郭と計算格子の位置関係等の算出の基本は外郭を形 成する個々の三角面である．航空機外郭を視覚的に紙 面に作図表現するためには，航空機のある空間内に一 つの視点を定める必要がある．そしてその視点を通る 任意の向きの直線と航空機の外郭を形成する各三角面 の交点を算出し，その交点の中で視点から最短距離の 交点をつくる三角面がその視点から見える外郭のもの であると一般的に判断した。さらに詳細に記述すれ ば，同一の三角面においても視点から見える部分とそ うでない部分が一般に生じる，一つの三角面を問題に したとき，その三角面上に視点からの他の三角面の辺 の投影線が一般に複数描かれる. 問題の三角面の辺を 含めこれらの投影線により三角面内に複数の多角形が 作られる，その多角形の一つの任意の点，たとえば図 形中心点，と視点を結ぶ直線上に他の三角面との交点 がない場合、問題の三角面上のその多角形の部分は視 点から見える部分と判断した．航空機の外郭を形成す るすべての三角面について上記の計算処理を行い，視 覚的に紙面に作図した．上述のすべての三角面内にで きる投影線から作られる多角形の総数は有限であり， 視線も有限の本数で全紙面を網羅てきる，また遠近効 果は，外郭座標值を視点からの距離および直交二平面 となす二つの視角で表わして加えた。

航空機の外郭の一例として第 6.7 おび 8 図にそ れぞれ平面，正面，側面の線図として示すように，胴 体，主賈，水平尾翼，垂直尾翼，エンジン・ナセルお よび主翼フラップから構成される民間旅客用航空機を 想定した形状を与えた，主龭は胴体中央部下方に設置 され上反角と後退角を持ち外翼内翼の区別を持たせ た.エンジン・ナセルは胴体後方の左右に一個ずつ配 置した，水平尾翼は垂直尾翼の上方に配置し下反角お よび後退角を持たせた．またフラップを左右の主翼に 一対備えた。この航空機の外郭を左上方に視点を置い て作図した例が第 9 図である。この例の場合，航空機 の外郭を形成する三角面の総数は約 4,000であり，同 図で外郭を描いている四辺形等の数は見えない部分も

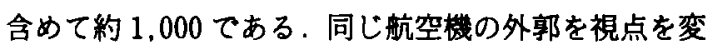
えて第 10 図に示した。また主翼からフラップを出し 


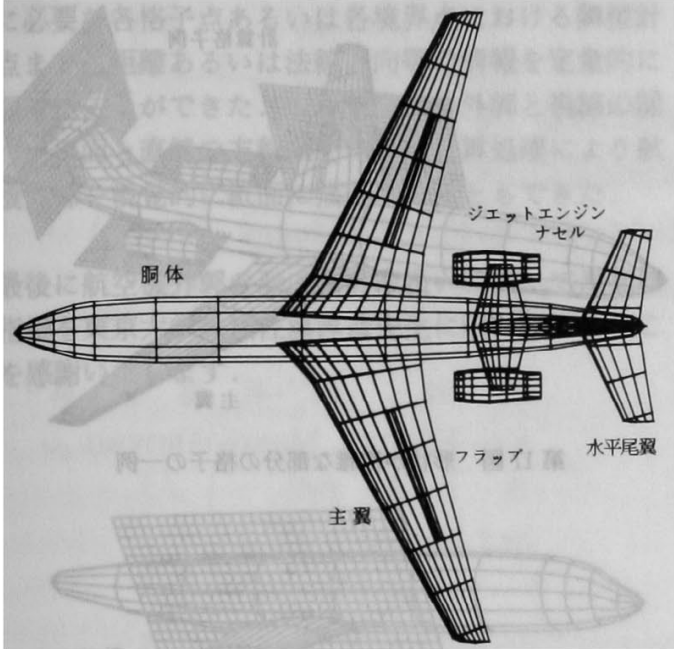

第 6 図 航空機構成部分の線図

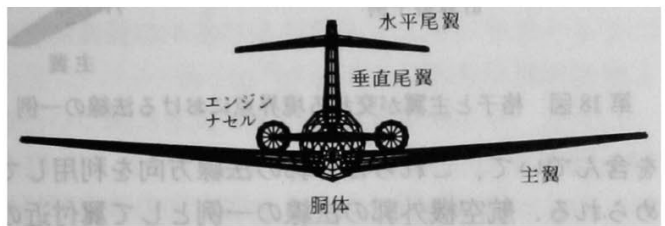

第 7 図 航空機構成部分の線図

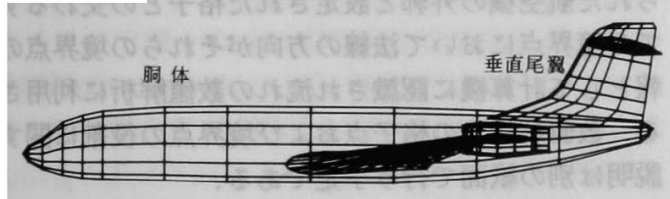

第 8 図 航空機構成部分の線図

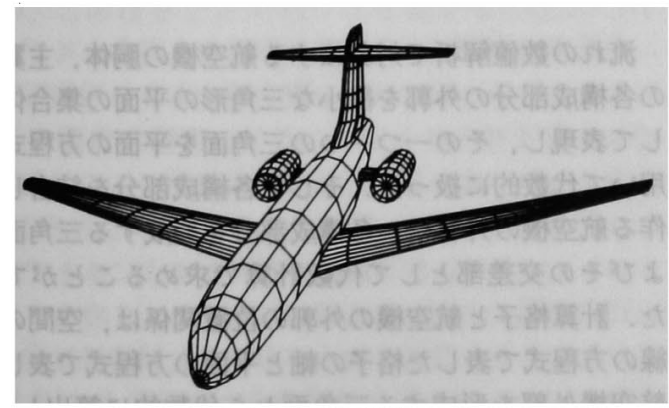

第 9 図 航空機外郭の一例

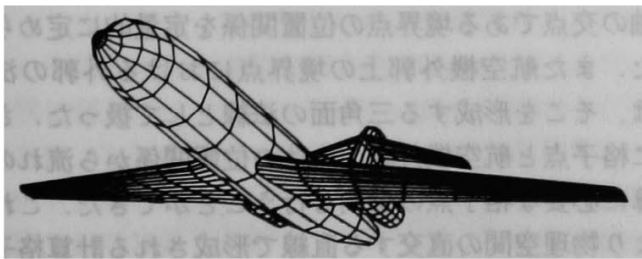

第 10 図視点を変えた堨合の航空楬外部
た状態の外郭を第 $11 ， 12$ 図に描いた。航空機の外郭 の座標值は各構成部分の座標値を独立に与え結合した ものであるから，各構成部分の配置，相対寸法，方 向等は自由に変更できるものである．第 13 図には上 述の航空機のエンジン・ナセルを主翼の墨下に配置し， 主買の胴体に対する位置を前方および上方に多少移動 させ，さらに水平尾翼に上反角を持たせて胴体側へ移 動させた航空機の外郭を描写した図である．他の視点 から見た同外郭を第 14 図に一例として示した。

3.2 計算格子と法線 与えられた航空機のまわり の流れの数值解析に先立って, 計算格子と航空機の外 郭の位置関係を定量的に計算機に認識させる必要があ

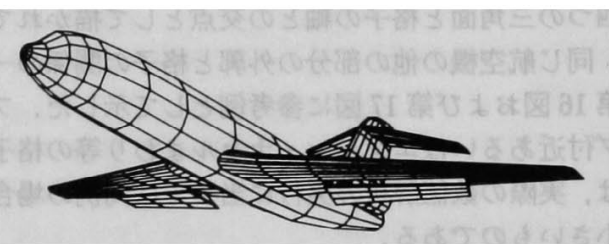

第 11 図 主嫼からフラップを出した状態の航空機外郭

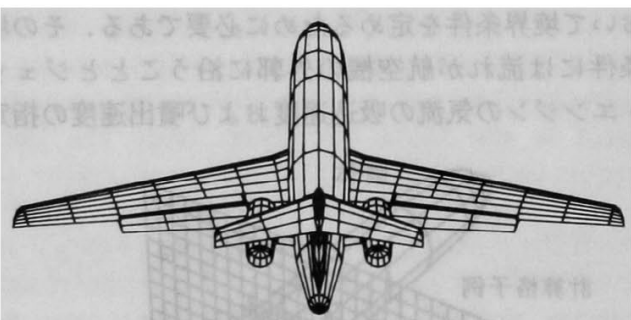

第 12 図 主賈からフラップを出した状管の航空機外郭

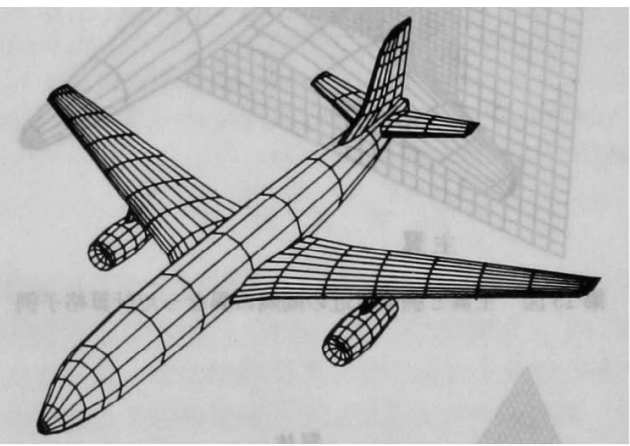

第 13 図 エンジンを主貢に付けた場合の航空機外郭

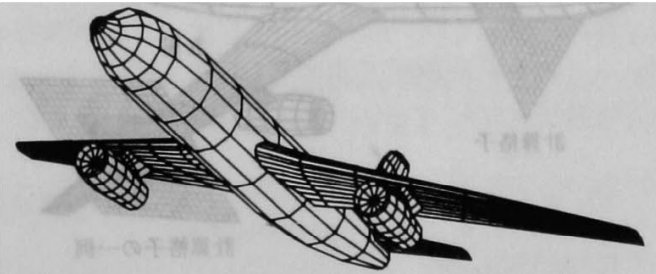

第 14 図 エンジンを主置に付けた場合の航空機外郭 
る. 設定された格子のすへてての格子点と格子と交わる 航空機外郭上のすべての境界点の位置関係を前述の直 線と平面の方程式から算出し，さらに各境界点の法線 方向を算出して格子点および境界点の情報として計算 機に認識させる．これらの格子点の情報を基にして流 れ場に属する格子点を選別する．これらの結果を用い て先の航空機の外郭図に加えて航空機周辺の一部の格 子を例として第 15 図に示した．航空機の寸法に対す る格子間隔は任意であり，航空機の部分的な形状ある いは必要度に応じて変えられるがこの図では参考例の ため格子間隔は粗くとった．格子の軸と航空機外郭の 交点は，同図でいえば外郭を描いている四辺形内にあ る四つの三角面と格子の軸との交点として描かれてい る. 同じ航空機の他の部分の外郭と格子の関係の一部 を第 16 図および第 17 図に参考例として示した.フラ ップ付近あるいはエンジン・ナセルまわり等の格子間 隔は，実際の数值解析の実行に当っては同例の場合よ り小さいものである.

航空機の外郭の法線方向は, 流れの数值解析の過程 において境界条件を定めるために必要である，その境 界条件には流れが航空機の外郭に沿うこととジェッ ト・エンジンの気流の吸込速度および噴出速度の指定

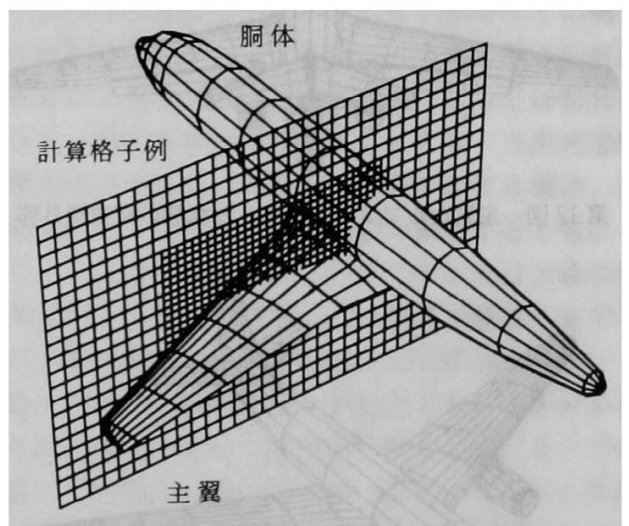

第 15 図主置と同体付近の問隔の異なった計算格子例

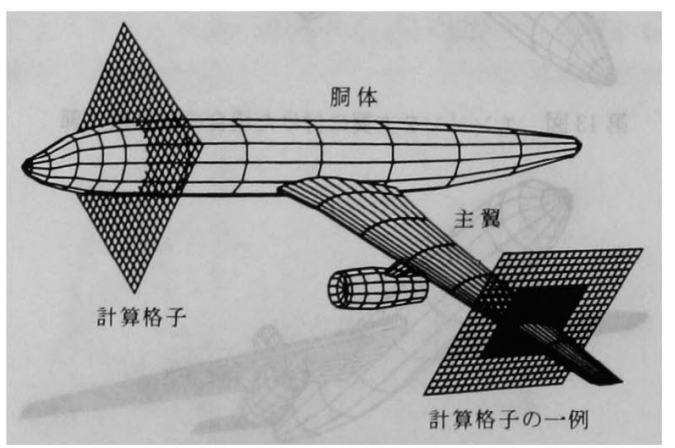

第 16 図 䏱体頭部上睓端付近の計算格子例

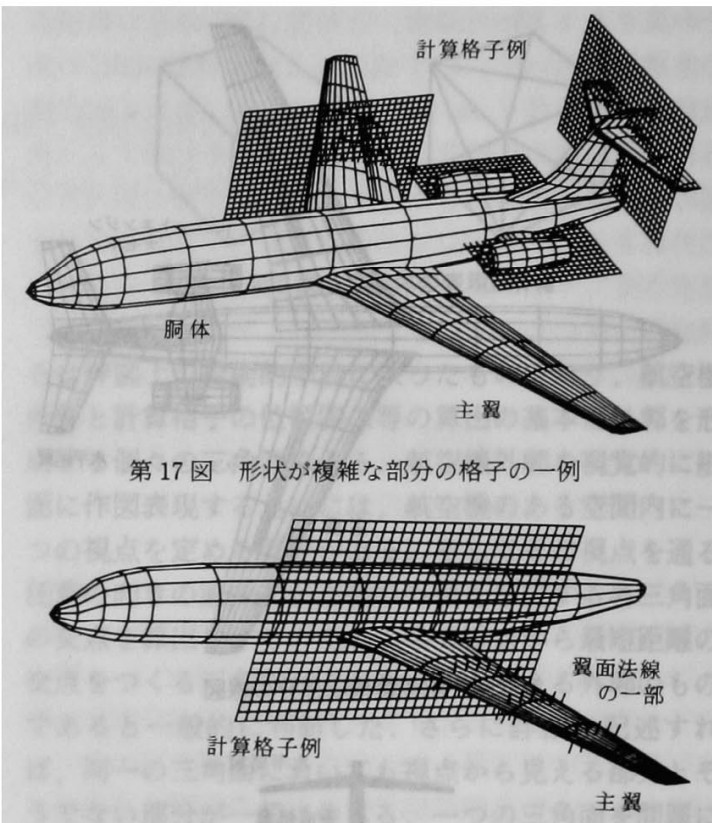

第 18 図 格子と主翼が交わる境界点における法線の一例

を含んていて、これらは外郭の法線方向を利用して定 められる.航空機外郭の法線の一例として翼付近の一 部について対応格子とともに第 18 図に示した。与え られた航空機の外郭と設定された格子との交わるすべ ての境界点において法線の方向がそれらの境界点の情 報として計算機に記識され流れの数俻解析に利用され る. 数值解析上の格子点および境界点の役割に関する 説明は別の紙面で行う予定である。

\section{4. むす $す$}

流れの数值解析で対象にする航空機の胴体，主翼等 の各構成部分の外郭を微小な三角形の平面の集合体と して表現し，その一つ一つの三角面を平面の方程式を 用いて代数的に扱った。 そして各構成部分を結合して 作る航空機の外郭は，各構成部分を形成する三角面お よびその交差部として代数計算で求めることができ た. 計算格子と航空機の外郭の位置関係は, 空間の直 線の方程式で表した格子の軸と平面の方程式で表した 航空機外郭を形成する三角面から代数的に算出した. その結果, 航空機の外郭近傍の格子点と外郭と格子の 軸の交点である境界点の位置関係を定量的に定められ た.また航空機外郭上の境界点における外郭の法線 は，そこを形成する三角面の法線として扱った。さら に格子点と航空機外郭の全体の位嘈関係吕ら流れの計 算に必夏な格子点の選別も行うことができた。これに より物理空間の直交する直線で形成される計算格子に おいて航空機のまわりの流れの差分計算を実行するた 
めに必要な各格子点あるいは各境界点における隣接計 算点までの距離あるいは法線方向等の情報を定量的に 把握することができた。また航空機の外郭と視線の関 係を，平面と直線の方程式を用いた計算処理により航 空機外郭を視覚的に紙面に描写することもできた。

最後に航空機外郭の形成面の取扱いに関して貴重な ご指摘を東京大学教授佐藤淳造先生に睗わりましたこ とを感謝いたします。

\section{参考文献}

1) Rubbert, P. E. and Saeris, G. R. : Review and Extention of a Three-dimensional Lifting Potential Flow Analysis Method for Arbitrary Configurations, AIAA Paper 72188 (1972).

2) Boppe, C. W.: Transonic Flow Field Analysis for WingFuselage Configurations, NASA CR-3243 May (1980).

3) Nakamura, M. : Numerical Design of Shockless Transonic Quasi-Aircraft, J. Physic. Soc. Jpn., 52 (1983), pp. 2706-2710.

4）福井常孝ほ加：線型代数学入門，内田老鶴團，東京， 1963. 